\title{
Ultrasound-guided psoas compartment block and general anesthesia for arthroscopic knee surgery: a case report
}

\author{
Artroskopik diz cerrabisi için genel anestezi ve ultrason rebberliğinde \\ psoas kompartman blok uygulamasi: Olgu sunumu
}

\author{
Emine Aysu ŞALVIZ, ${ }^{1}$ Yavuz GÜRKAN, ${ }^{2}$ Murat TEKIN,${ }^{2}$ Levent BULUÇ ${ }^{3}$
}

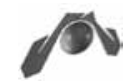

Summary

Anesthetizing the lumbar plexus at its origin facilitates a more "complete" psoas compartment block compared to peripheral approaches. It is usually performed using surface anatomical landmarks, and the site for local anesthetic injection is confirmed by observing quadriceps muscle contraction to peripheral nerve stimulation. Ultrasound may provide guidance alone or together with the aid of nerve stimulation during nerve blocks. We present a 48-year-old male patient, American Society of Anesthesiologists (ASA) physical status II, who refused spinal anesthesia, and underwent knee arthroscopy with ultrasoundguided psoas compartment block and general anesthesia. Following the standard monitoring and lateral decubitus positioning, the vertebral body, psoas, erector spinae, and quadratus lumborum muscles and hyperechoic nerve roots of the patient were visualized at the level of L4-5 with curvilinear ultrasound probe. The needle was inserted with ultrasound guidance, and correct tip position was confirmed with quadriceps contraction. Then, the mixture of $30 \mathrm{~mL}$ local anesthetic $(10 \mathrm{~mL} 2 \%$ lidocaine and $20 \mathrm{ml}$ \% levobupivacaine) was injected at the estimated position of the lumbar plexus (junction of the posterior third and anterior two-thirds of the psoas muscle). He also received general anesthesia for the surgery. Anesthesia and surgical procedures were completed successfully without any additional anesthetic/analgesic requirement or complication. The postoperative period was pain-free both at rest and during mobilization for 24 hours. This case report shows that ultrasoundguided psoas compartment block is feasible and efficient for peri- and postoperative analgesia during knee arthroscopy.

Key words: Knee arthroscopy; psoas compartment block; ultrasound.

\begin{abstract}
Özet
Psoas kompartman bloğu, lumbar pleksusun kökler bizasında bloke edilmesi sebebiyle periferik yaklaşımlara göre daha tam bir bloktur. Genellikle yüzeyel anatomik işaret noktaları kullanılarak blok lokalizasyonu belirlenir ve lokal anestezik enjeksiyonu periferik sinir stimülatörü ile kuadriseps kasının kontraksiyonu görülerek uygulanır. Ultrason sinir bloklarında tek başına veya sinir stimülatörü yardımı ile rebberlik sağlayabilir. Biz, bu yazıda spinal anestezi girişimini reddeden, genel anestezi ve ultrason rebberliğinde psoas kompartman bloğu altında diz artroskopi cerrabisi geçiren, 48 yaşında, ASA II, erkek hasta ile ilgili deneyimimizi sunduk. Hastaya standart monitorizasyon uyguland ve lateral dekübit pozisyon verilmesi sonrasinda vertebra, psoas, erektor spina and kuadratus lumborum kaslar L4-5 seviyesinde konveks prob ile gözlendi. İğne ultrason rebberliğinde ilerletildi ve iğne ucunun lokalizasyonu kuadriseps kas kontraksiyonu ile doğrulandı. Otuz mL lokal anestezik karıșımının (10 mL \%2'lik lidokain ve $20 \mathrm{~mL} \% 5$ 'lik levobupivakain) lumbar pleksus etrafina enjekte edilmesinin ardından hastaya genel anestezi uyguland. Anestezi ve cerrabi işlem ek anestezik/analjezik ibtiyacı veya komplikasyon olmaksızın başarıyla tamamland. Hastanın ameliyat sonrası dönemde istirahatte ya da mobilizasyonda ilk 24 saatte ağr ş̧ikayeti olmadı. Bu olgu sunumu, ultrason rebberliğinde psoas kompartman bloğunun diz artroskopi cerrabisinde ameliyat esnası ve sonrası analjezi için uygun ve etkin bir yöntem olduğunu göstermektedir.
\end{abstract}

Anahtar sözcükler: Diz artroskopisi; psoas kompartman bloğu; ultrason.

'Department of Anesthesiology and Reanimation, Şanlıurfa Training and Research Hospital, Sanliurfa;
2Department of Anesthesiology and Reanimation, Kocaeli University Faculty of Medicine, Kocaeli;
3Department of Orthopedics and Traumatology, Kocaeli University Faculty of Medicine, Kocaeli
'Şanlıurfa Eğitim ve Araştırma Hastanesi, Anesteziyoloji ve Reanimasyon Kliniği, Şanlıurfa;
2Kocaeli Universitesi Tıp Fakültesi, Anesteziyoloji ve Reanimasyon Anabilim Dall, Kocaeli;
'Kocaeli Üniversitesi Tıp Fakültesi, Ortopedi ve Travmatoloji Anabilim Dalı, Kocaeli

Submitted (Başvuru tarihi) 24.02.2012 Accepted after revision (Düzeltme sonrası kabul tarihi) 15.06.2012
Current affiliation / Şimdiki kurumu:

'Department of Anesthesiology and Reanimation, Istanbul University Istanbul Faculty of Medicine Istanbul;

'Istanbul Ünivesitesi İstanbul Tıp Fakültesi, Anesteziyoloji ve Reanimasyon Anabilim Dalı, istanbul

Correspondence (İletişim): Dr. Emine Aysu Şalvız. İstanbul Ünivesitesi, İstanbul Tıp Fakültesi, Anesteziyoloji ve Reanimasyon Anabilim Dalı, Çapa, İstanbul, Turkey.

Tel: +90 - 212 - 4142000 e-mail (e-posta): aysusalviz@gmail.com 


\section{Introduction}

The psoas compartment block (PCB) technique is useful in anesthetizing the lumbar plexus at its origin. Successfully placing local anesthetic (LA) at the level of the lumbar plexus roots (junction of the posterior third and the anterior two-thirds of the psoas muscle) is a more "complete" method compared to peripheral approaches. ${ }^{[1-4]}$ It provides the blockade of the femoral, obturator and lateral cutaneous nerves of the thigh with a single injection. ${ }^{[3-5]}$ Therefore, it may be used for anesthesia and analgesia of anterior, medial, and lateral procedures of the thigh such as skin grafts and femoral osteotomy, total knee replacement, ${ }^{[6]}$ total hip replacement, ${ }^{[7,8]}$ hip fractures, ${ }^{[9,10]}$ knee arthroscopy, ${ }^{[11]}$ anterior and posterior cruciate ligament reconstructions ${ }^{[12]}$ and chronic hip pain. ${ }^{[13]}$

The PCB technique is traditionally performed using surface anatomical landmarks and observing quadriceps muscle contraction to peripheral nerve stimulation. ${ }^{[3]}$ Lately, there has been a rise in the use of ultrasound to visualize the sonoanatomy of lumbar plexus and to guide the PCBs. Ultrasound-guided regional anesthetic techniques of the lower limb can be challenging because of the muscles and fat which surround the nerves, ${ }^{[5,14]}$ however technological improvements of ultrasound equipment have allowed better visualization of the nerves and the other anatomical structures. The lumbar plexus and the posterior part of the psoas muscle, although deep, were examined in cadavers and just in a few cases successfully. ${ }^{[1,3,15,16]}$ We present a case, who underwent a knee arthroscopy with successful ultrasound-guided PCB and general anesthesia.

\section{Case Report}

A 48-year-old male, ASA physical status II patient with hypertension was scheduled for knee arthroscopy procedure. Patient history revealed that, the patient had undergone appendectomy, nephrolitiazis operations under general anesthesia and knee arthroscopy, hallux valgus, hemorrhoid operations under spinal anesthesia. Moreover, he had had coronary angiography twice by the reason of chest pain and hypertension, and got normal results. No abnormalities were noted on his preoperative blood tests, chest X-ray and physical examination. In order to provide a more complete anesthesia and analgesia for this patient, who refused to undergo spinal anesthesia, an ultrasound-guided PCB and general anesthesia was planned.

On arrival to the holding area where blocks were performed, standard monitoring (pulse-oxymetry, heart rate (HR), noninvasive blood pressure (NIBP) and ECG) was applied. A 20-gauge intravenous (IV) cannula was placed on the right hand of the patient and a free running infusion of saline was started. Oxygen $2 \mathrm{~L} / \mathrm{h}$ was applied via mask. Sedation was provided with $3 \mathrm{mg}$ IV midazolam after the lateral decubitus position with the left operative side up, the hips and the knees flexed. After disinfection and sterile draping, sterile gel was applied to the procedure area. A low frequency curvilinear ultrasound probe (1-8 MHz, Esaote My Lab 30, Genoa, Italy) was placed at the level of L4-5 in the transverse plane (Figure 1). Vertebral body, articular process, psoas, erector spina, and quadratus lumborum muscles were visualized (Figure 2). After LA skin infiltration, a 22-gauge $100 \mathrm{~mm}$ insulated needle (Pajunk, Geisingen, Germany) was inserted lateral to the probe, using in-plane technique. The correct tip position was confirmed with quadriceps contraction at $8 \mathrm{~cm}$ by neurostimulator $0.5 \mathrm{~mA}$. Then, LA mixture of $30 \mathrm{~mL}(10 \mathrm{~mL} 2 \%$ lidocaine and $20 \mathrm{~mL} \mathrm{5 \%} \mathrm{levobupivacaine)} \mathrm{was} \mathrm{injected} \mathrm{incre-}$ mentally in fractioned doses with frequent aspiration to detect any possible intravascular puncture. The LA spread was observed on transverse axis scan.

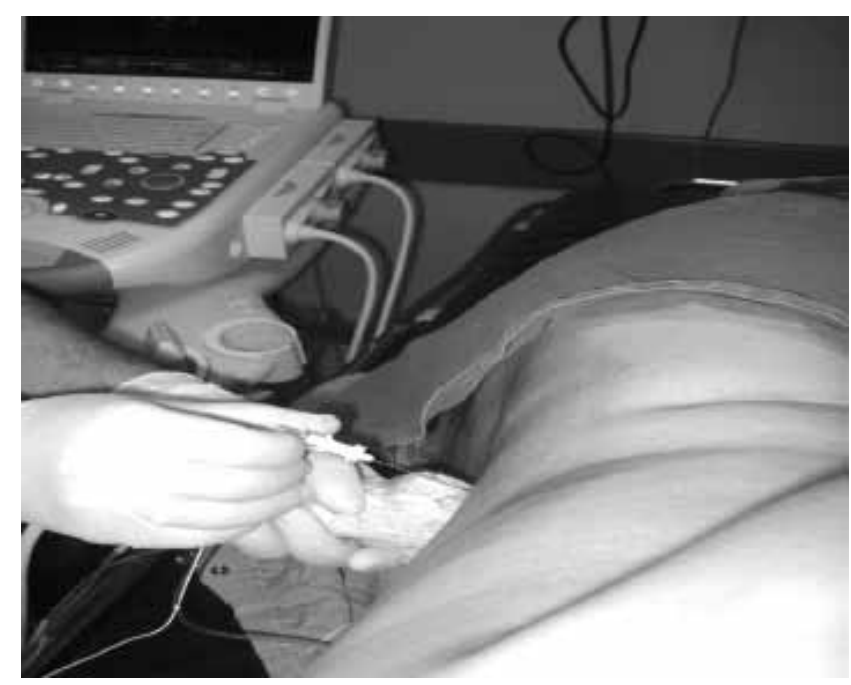

Figure 1. A low frequency curvilinear ultrasound probe was placed at the level of L4-5 in the transverse plane while the patient is placed in the right lateral decubitus position. 


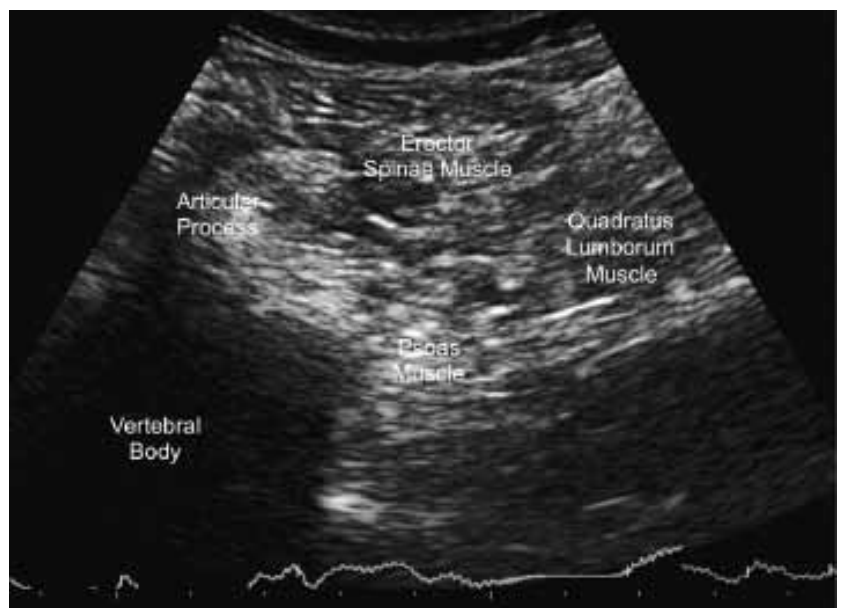

Figure 2. The vertebral body, articular process, psoas, erector spina, and quadratus lumborum muscles of the patient were visualized with a low frequency curvilinear ultrasound probe.

Successful block was confirmed in 20 minutes by decreased sensation in terminal nerves of the lumbar plexus (femoral, lateral femoral cutaneous, and obturator) and quadriceps weakness.

Then, the patient was taken to the operating room. Following the application of standard monitoring and obtaining normal vital signs, general anesthesia was induced with propofol $2.5 \mathrm{mg} \mathrm{kg}^{-1}$ and fentanyl $1 \mu \mathrm{g} \mathrm{kg}^{-1}$ iv. Laryngeal mask (number 4) was placed for airway protection and anesthesia was then maintained with $1.5-2 \%$ sevoflurane in $\mathrm{N}_{2} \mathrm{O}$ and $\mathrm{O}_{2}(1: 1$ ratio). Knee arthroplasty and anesthesia procedures were successfully completed within 50 minutes without any additional anesthetic/analgesic requirement. Diclofenac $75 \mathrm{mg}$ was ordered as a rescue analgesic that could be repeated every $6 \mathrm{~h}$ with a maximum daily dose of $300 \mathrm{mg}$.

The patient was discharged on the next day. He was very pleased because of pain free postoperative period both at rest and during mobilization, and his analgesic consumption was 0 during the postoperative first 24 hours.

\section{Discussion}

Knee arthroscopy is one of the most commonly performed elective ambulatory orthopedic procedures and associated with moderate to severe, often poorly controlled, postoperative pain. ${ }^{[4,17]}$ Various types of anesthesia including neuraxial blocks, general, and peripheral nerve blocks have been performed for these procedures. ${ }^{[18-21]}$ Central neuraxial blocks and general anesthesia provide effective anesthesia, however neuraxial blocks cause nausea/emesis, urinary retention, post-dural puncture, hemodynamic changes, motor weakness in the lower extremity and on the other hand general anesthesia is reported with high postoperative pain scores, and low satisfaction ratings. ${ }^{[4,12]}$ However, peripheral nerve blocks have advantages of providing limb-specific anesthesia/analgesia without extended muscle weakness, allowing early ambulation, enabling effective physiotherapy and early discharge. ${ }^{[4,22,23]}$

Although femoral nerve block is easy to perform, the obturator and lateral femoral cutaneous nerves are not consistently blocked with this technique. ${ }^{[24]}$ On the other hand, the lumbar plexus is made up of the L1 through L5 spinal nerve roots. As the roots of the lumbar plexus depart from their spinal nerves and emerge from the intervertebral foramen, they enter the posterior third or junction of the posterior third and the anterior two-thirds of the psoas muscle. ${ }^{[1-4,25]}$ In contrast to the femoral approach, the PCB reliably produces blockade of the entire lumbar plexus with high success rate. ${ }^{[14,24]}$ Therefore, PCB with general anesthesia was chosen to provide complete peri-/post-operative analgesia and anesthesia during our clinical practice.

To reach the lumbar plexus by surface anatomical landmarks is useful but can vary among patients. Several techniques as loss of resistance, elicitation of paresthesia, and quadriceps muscle contraction to nerve stimulation have been described at different levels using surface anatomical landmarks in the literature. ${ }^{[2,9,16,24,26,27]}$ However, epidural spread of the LA, systemic toxicity, renal hematoma, total spinal anesthesia and circulatory cases have been reported as complications of these approaches. ${ }^{[28-33]}$ These complications are usually related with failed or multiple attempts, or inadvertent vascular injuries. [33] With the use of ultrasound for imaging of the individual anatomy and real-time needle guidance, the efficacy of the PCB might be increased and such complications might be avoided. ${ }^{[16]}$

Ultrasound guidance during PCB may offer several advantages compared to the traditional methods. The related anatomy and target structures are clearly 
identified, the advancement of the needle to the posterior part of the psoas muscle and meanwhile the spread of the LA during the injection can be observed. ${ }^{[2,3,32]}$ This may allow the anesthesiologist to perform the PCB safely and successfully. Furthermore, two different techniques of ultrasound-guided PCB as transverse and longitudinal approaches have been described. ${ }^{[1,3,16,17]}$ Longitudinal technique may cause bilateral spread and systemic LA toxicity because of the rapid absorption of large volumes or inadvertent injection into one of the large paravertebral blood vessels. ${ }^{[5]}$ Therefore, we preferred transverse technique and were able to visualize the kidney, vertebral body, spinous, articular, and transverse processes, psoas, erector spina and quadratus lumborum muscles clearly in order to perform a successful block and avoid the puncture.

Our observation of the lumbar plexus location in the posterior part of the psoas muscle was coherent with the previous data. ${ }^{[2,3]}$ The location of the plexus and the tip of the needle were confirmed both by ultrasound and nerve stimulator. The block was successfully completed after one attempt. Paresthesia, blood aspiration or injury to surrounding structures were not noted during the procedure.

As a result, this case report describes that a successful ultrasound guided PCB technique provides a pain free peri-/post-operative period without any additional anesthetic or analgesic. This shows that ultrasound-guided PCB is a feasible and efficient technique for knee arthroscopy. Inspite of the impressive cadaver study and case report results, the published prospective investigations are limited. Further studies are necessary to evaluate the rate of success, safety and efficacy of the ultrasound guided PCB technique.

\section{Conflict-of-interest issues regarding the author- ship or article: None declared.}

\section{Peer-rewiew: Externally peer-reviewed.}

\section{References}

1. Kirchmair L, Entner T, Wissel J, Moriggl B, Kapral S, Mitterschiffthaler G. A study of the paravertebral anatomy for ultrasound-guided posterior lumbar plexus block. Anesth Analg 2001;93(2):477-81. CrossRef

2. Farny J, Drolet P, Girard M. Anatomy of the posterior approach to the lumbar plexus block. Can J Anaesth 1994;41(6):480-5.

3. Karmakar MK, Ho AM, Li X, Kwok WH, Tsang K, Ngan Kee WD. Ultrasound-guided lumbar plexus block through the acoustic window of the lumbar ultrasound trident. $\mathrm{Br} J$ Anaesth 2008;100(4):533-7. CrossRef

4. Greengrass RA. Posterior lumbar plexus block. Tech Reg Anesth Pain Manag 2003:7(1):3-7. CrossRef

5. Marhofer P, Harrop-Griffiths W, Willschke H, Kirchmair L. Fifteen years of ultrasound guidance in regional anaesthesia: Part 2-recent developments in block techniques. $\mathrm{Br} \mathrm{J} \mathrm{An-}$ aesth 2010;104(6):673-83. CrossRef

6. Luber MJ, Greengrass R, Vail TP. Patient satisfaction and effectiveness of lumbar plexus and sciatic nerve block for total knee arthroplasty. J Arthroplasty 2001;16(1):17-21. CrossRef

7. Capdevila $X$, Macaire $P$, Dadure $C$, Choquet $O$, Biboulet $P$, Ryckwaert $Y$, et al. Continuous psoas compartment block for postoperative analgesia after total hip arthroplasty: new landmarks, technical guidelines, and clinical evaluation. Anesth Analg 2002;94(6):1606-13. CrossRef

8. Türker G, Uçkunkaya N, Yavaşçaoğlu B, Yilmazlar A, Ozçelik S. Comparison of the catheter-technique psoas compartment block and the epidural block for analgesia in partial hip replacement surgery. Acta Anaesthesiol Scand 2003;47(1):306. CrossRef

9. Ho AM, Karmakar MK. Combined paravertebral lumbar plexus and parasacral sciatic nerve block for reduction of hip fracture in a patient with severe aortic stenosis. Can J Anaesth 2002;49(9):946-50. CrossRef

10. de Visme V, Picart F, Le Jouan R, Legrand A, Savry C, Morin V. Combined lumbar and sacral plexus block compared with plain bupivacaine spinal anesthesia for hip fractures in the elderly. Reg Anesth Pain Med 2000;25(2):158-62. CrossRef

11. Jankowski CJ, Hebl JR, Stuart MJ, Rock MG, Pagnano MW, Beighley $\mathrm{CM}$, et al. A comparison of psoas compartment block and spinal and general anesthesia for outpatient knee arthroscopy. Anesth Analg 2003;97(4):1003-9. CrossRef

12. Klein SM, Greengrass RA, Grant SA, Higgins LD, Nielsen KC, Steele SM. Ambulatory surgery for multi-ligament knee reconstruction with continuous dual catheter peripheral nerve blockade. Can J Anaesth 2001;48(4):375-8. CrossRef

13. Goroszeniuk T, di Vadi PP. Repeated psoas compartment blocks for the management of long-standing hip pain. Reg Anesth Pain Med 2001;26(4):376-8. CrossRef

14. Saranteas T. Limitations in ultrasound imaging techniques in anesthesia: obesity and muscle atrophy? Anesth Analg 2009;109(3):993-4. CrossRef

15. Kirchmair L, Entner T, Kapral S, Mitterschiffthaler G. Ultrasound guidance for the psoas compartment block: an imaging study. Anesth Analg 2002;94(3):706-10. CrossRef

16. Morimoto M, Kim JT, Popovic J, Jain S, Bekker A. Ultrasoundguided lumbar plexus block for open reduction and internal fixation of hip fracture. Pain Pract 2006;6(2):124-6. CrossRef

17. O'Donnell BD, lohom G. Regional anesthesia techniques for ambulatory orthopedic surgery. Curr Opin Anaesthesiol 2008;21(6):723-8. CrossRef

18. Mulroy MF, Larkin KL, Hodgson PS, Helman JD, Pollock JE, Liu SS. A comparison of spinal, epidural, and general anesthesia for outpatient knee arthroscopy. Anesth Analg 2000;91(4):860-4. CrossRef

19. Jacobson E, Forssblad M, Rosenberg J, Westman L, Weidenhielm L. Can local anesthesia be recommended for routine use in elective knee arthroscopy? A comparison between local, spinal, and general anesthesia. Arthroscopy 
2000;16(2):183-90. CrossRef

20. Ilfeld BM, Le LT, Meyer RS, Mariano ER, Vandenborne K, Duncan PW, et al. Ambulatory continuous femoral nerve blocks decrease time to discharge readiness after tricompartment total knee arthroplasty: a randomized, triple-masked, placebo-controlled study. Anesthesiology 2008;108(4):703-13.

21. Gürkan Y, Kılıçkan L, Canatay H, Müezzinoğlu S, Toker K. Artroskopik diz cerrahisinde farklı anestezi yöntemlerinin karşılaştırılması. Türk Anesteziyoloji ve Reanimasyon Cemiyeti Mecmuası 2002;30:408-12.

22. Capdevila $X$, Barthelet $Y$, Biboulet $P$, Ryckwaert $Y$, Rubenovitch J, d'Athis F. Effects of perioperative analgesic technique on the surgical outcome and duration of rehabilitation after major knee surgery. Anesthesiology 1999;91(1):8-15. CrossRef

23. Singelyn FJ, Deyaert $M$, Joris $D$, Pendeville $E$, Gouverneur $J M$. Effects of intravenous patient-controlled analgesia with morphine, continuous epidural analgesia, and continuous three-in-one block on postoperative pain and knee rehabilitation after unilateral total knee arthroplasty. Anesth Analg 1998;87(1):88-92. CrossRef

24. Parkinson SK, Mueller JB, Little WL, Bailey SL. Extent of blockade with various approaches to the lumbar plexus. Anesth Analg 1989;68(3):243-8. CrossRef

25. Di Benedetto P, Pinto G, Arcioni R, De Blasi RA, Sorrentino L, Rossifragola I, et al. Anatomy and imaging of lumbar plexus.
Minerva Anestesiol 2005;71(9):549-54.

26. Chayen D, Nathan H, Chayen M. The psoas compartment block. Anesthesiology 1976;45(1):95-9. CrossRef

27. Winnie AP, Ramamurthy S, Durrani Z, Radonjic R. Plexus block for lower extremity surgery. Anesth Rev 1974;(1)1:11-6.

28. Huet O, Eyrolle LJ, Mazoit JX, Ozier YM. Cardiac arrest after injection of ropivacaine for posterior lumbar plexus blockade. Anesthesiology 2003;99(6):1451-3. CrossRef

29. Breslin DS, Martin G, Macleod DB, D'ercole F, Grant SA. Central nervous system toxicity following the administration of levobupivacaine for lumbar plexus block: $A$ report of two cases. Reg Anesth Pain Med 2003;28(2):144-7. CrossRef

30. Pousman RM, Mansoor Z, Sciard D. Total spinal anesthetic after continuous posterior lumbar plexus block. Anesthesiology 2003;98(5):1281-2. CrossRef

31. Aida S, Takahashi $H$, Shimoji K. Renal subcapsular hematoma after lumbar plexus block. Anesthesiology 1996;84(2):452-5.

32. Mullanu Ch, Gaillat F, Scemama F, Thibault S, Lavand'homme $P$, Auffray JP. Acute toxicity of local anesthetic ropivacaine and mepivacaine during a combined lumbar plexus and sciatic block for hip surgery. Acta Anaesthesiol Belg 2002;53(3):2213.

33. Aveline C, Bonnet F. Delayed retroperitoneal haematoma after failed lumbar plexus block. Br J Anaesth 2004;93(4):58991. CrossRef 